Faraday's Diary :

being the various Philosophical Notes of Experimental Investigation made by Michael Faraday, D.C.L., F.R.S., during the Years 1820-1862 and bequeathed by him to the Royal Institution of Great Britain, Now, by order of the Managers, printed and published for the first time, under the editorial supervision of Thomas Martin. Vol. 6 : Nov. 11, 1851Nov. 5, 1855. Pp. xiv $+495+8$ plates. (London: G. Bell and Sons, Ltd., 1935.) 7 vols., $£ 12$ 12s. net.

THIs, the penultimate volume of Faraday's Diary, covers the period from November 1851 to November 1855. In the main, the topics treated are lines of magnetic force, the construction of a magnetic torsion balance and the measurements made therewith, electrodynamic induction in liquids and magnecrystallic action. The MS. of this section of the Diary is noteworthy as containing a number of "the actual specimens prepared by Faraday in 1851 to illustrate the delineation of lines of magnetic force by iron filings. The filings were fixed on cartridge paper by means of gum water, sometimes mixed with a solution of 'the red ferro-prussiate of potassa' (apparently potassium ferricyanide), which was found to leave a blue impression of the pattern after the filings had been removed or worn off". A number of the specimens have survived the changes of more than eighty years, and this volume contains collotype reproductions of some of the more suitable specimens. The frontispiece is a reproduction of the famous painting which represents Faraday giving the Christmas lectures of 1855-56 before the Prince Consort, the Prince of Wales and Prince Alfred.

The volume maintains the interest of its predecessors. Detailed consideration of its contents is deferred until the appearance of the concluding volume, when opportunity will be taken to discuss the whole work.

A. F.

Die Blutsverwandschaft im Volk und in der Familie: ein Beitrag zur menschlichen Lebenskunde (Anthropologie). Von Dr. Walther Jankowsky. Pp. viii + $166+12$ plates. (Stuttgart: E. Schweizerbart'sche Verlagsbuchhandlung (Erwin Nägele) G.m.b.H., 1934.) 6 gold marks.

DR. JANKowsky here enters upon an investigation of no little general interest, as well as of importance in the present standing of racial studies and the question of human inheritance. His central problem is that of resemblances in appearance, both as between members of a family and as between individuals who are not known to be personally related. He also brings into consideration the biological character and significance of such phenomena of resemblance. $\mathrm{He}$ discusses successively the concepts of blood relationship, resemblance factors, individual heredity and pseudo-resemblances. Further, he examines and sets out the methods of investigation applicable to the investigation of the specific problem. One of the most important aspects of the question, on which his views will be found of no little interest to the ethnologist and the student of human heredity, is that of the degree to which significance is to be attached to resemblances without personal relationship in the light of the theory of chance and with special reference to the conditions of descent within a given population.

Dr. Jankowsky's cautious conclusions and wellmarshalled arguments, in what is admittedly an obscure field, will serve as a useful corrective of overhasty generalisations which too frequently go beyond what a scientific interpretation of the evidence would admit.

\section{Anorganisch Chemisches Praktikum :}

für Studierende der Chemie und anderer Naturwissenschaftlicher Fächer. Von Prof. Dr. Wilhelm. Manchot. Pp. viii +103. (Dresden und Leipzig : Theodor Steinkopff, 1935.) 4.30 gold marks.

This course, by one who has made important contributions to inorganic chemistry, is based on the axiom that a student of chemistry should be given the opportunity of becoming acquainted with the appearance and reactions of as many materials as he can in the time available, since this opportunity may never be available in his later career. By com. bining a course on qualitative analysis with preparative experiments he has attempted to provide a wider basis of instruction, and since this course has been followed in his own institution at Munich, it is obviously a possible one. The order seems at first sight unusual, since experiments on potassium compounds, for example, are followed by halogens, these by silica and silicates, and hydrogen peroxide comes between oxyacids of sulphur and the oxides of nitrogen. Whilst this arrangement may have some advantages as proceeding from less to more difficult experiments, it would seem to conflict with the usual order of lecture courses and would probably not be found satisfactory in English universities.

The Socialization of the Electrical Supply Industry By G. H. (Published for the New Fabian Research Bureau.) Pp. 104. (London : Victor Gollancz, Ltd., 1934.) 3s. 6d. net.

This survey of the electric supply industry is published under the auspices of the New Fabian Research Bureau, but the author alone is responsible for the views expressed. The conclusions are substantially in agreement with those in the Labour Party Policy Report No. 3. The ownership of local authority and company undertakings will be transferred to a reconstituted Central Electricity Board. The Central Electricity Board would issue new bonds secured on the revenue from the whole supply industry of the country in payment for the ownership. Difficulties in the way of doing this are clearly explained. Similar difficulties will arise in the socialisation of all indus. tries. The present average yield on electric lighting shares is about 4 per cent; this would be replaced by redeemable bonds giving $3 \frac{1}{2}$ per cent and so the capital charges would be reduced by about 12 per cent. The advantages of mutual co-operation between gas and electricity supply are pointed out. One advantage of railway electrification would be to cheapen the cost of supply from the grid. The book is well written and free from dogmatism. 